\title{
Cultural Discontinuity In Post-Mao China: An Itinerant Ethnography Of McDonald's Beijing
}

Noel M. Murray, (E-mail: nmurray@champman.edu), Chapman University

\begin{abstract}
Universalistic approaches cannot account for the diversity of culture in a rapidly changing postcommunist society. Different age cohorts within countries may exhibit dissimilar values and behavioral orientations. This article lays a foundation for the use of broader philosophical and methodological frameworks for the study of culture in an age of globalization. Bourdieu's concepts of "habitus" and "hysteresis effect" are described and applied to a study of post-Mao consumer food culture in China. Food consumption in China is situated in a historical, political and ideological context. McDonald's Beijing is examined as part of an itinerant ethnography to illustrate the contested meanings of a popular transnational cultural icon.
\end{abstract}

\section{Introduction}

1 n 1871 E.B. Tylor described culture as "that complex whole which includes knowledge, belief, art, morals, law, customs, and other capabilities and habits acquired by man as a member of society". Contemporary definitions of culture echo these essential elements and suggest a construct that is relatively stable over time (Hofstede 1991; Terpstra and David 1991). Hence research on culture focuses on assumed stable properties as a way of classifying cultures on dimensions such as individualism, masculinity, or power distance (Hofstede 1994; Hampden-Turner and Trompenaars 2000). Questions have been raised about the ability of these classification schemes to make meaningful predictions about consumption patterns (de Mooij, 1994). Countries with similar scores on a particular dimension frequently have distinctly different buying behaviors. Bhabha (1994) provides a convincing argument why different cultures are "incommensurables" and cannot be categorized into universalistic frameworks such as those of Hofstede. Perhaps the central limitation of such cross-sectional studies however, is that they focus on culture as a static construct, representing enduring values and behavioral dispositions. These universalistic frameworks seem less tenable in recent years with the rapid decline of communism worldwide and its replacement with market oriented economic systems.

Many countries have experienced a type of "culture shock" whereby old knowledge and belief systems no longer provide a guiding light to function in society (Kovacs, 2002). Art no longer serves goals of the State and the morality of postponed consumption is replaced with the call "to get rich is glorious". Legal systems are no longer ad hoc pretensions to a rule of law and are replaced with codified statutes. Customs and behavior patterns once deemed noble are now scorned on as backward by a new generation (Becker, 2000). Globalization, chiefly through the vehicle of popular culture, has brought about a greater level of integration and interconnectedness among different cultures, but not necessarily a concomitant homogeneity of cultures. The communist system under Mao, with its economic shortages and ideological controls, created the pre-conditions for acceleration towards a mass consumer culture among China's urban middleclass. Today, more than ever, culture must be analyzed as a dynamic, multifaceted, intergenerational process. The analysis of global cultures requires a scholarship that is more attentive to the qualities of change and patterns of influence than to determination of fixed essences. Culture is critical to an understanding of consumer behavior since the things we desire are seldom simple and immediately present to

Readers with comments or questions are encouraged to contact the authors via email. 
consciousness. Our desires may be abstractions like true love or freedom, complexities like protecting one's child, or instrumental values like looking professional.

In post communist economies such as Eastern Europe and China cultural change has been rapid, with marked differences in value systems between different age cohorts. Ariga and colleagues, for example, describe China's three generations (1997): The first generation is aged 45 to 59. They are the generation of the socialist society and many work for state owned enterprises. The second generation is aged 30 to 44 . They lost an opportunity to get a proper education. They have modest income at state owned enterprises, but as a result of China's one-child policy they will spend money on a "Little Emperor." The third generation is aged 18 to 29. They have a good educational background and are optimistic about the market economic system. Intergenerational cultural heterogeneity however is commonplace, and may be found in both developing economies such as Thailand and Malaysia and developed economies such as Japan and Germany (Berger and Huntington, 2002). Clearly, crosssectional, multi-country classification analyses are not designed to capture dynamic and heterogeneous cultural systems within countries. Even the three generations classification scheme only accurately describes the urban culture within China; it says little of the one billion peasant farmers. Cultural discontinuity can also occur within regions e.g., the urban high-technology yuppie culture of Bangalore, India (Srinivas, 2002).

The concern in this paper is twofold. First, marketers need a better understanding of culture as a dynamic process that relates to the forces of globalization. Second, we need to broaden the scope of cultural investigation and avail of a more diverse range of methodological tools and philosophical modes of inquiry. In this paper I show how contributions from the field of cultural studies can expand our understanding of the dynamic of globalization and culture. In particular, I focus on the potential contributions from the French sociologist, Pierre Bourdieu and his concepts of habitus and hysteresis effect. Next, I illustrate the application of these approaches to deconstructing contemporary Chinese food culture through a frame analysis of Chinese television commercial for McDonalds. Finally, I suggest a new research agenda for the study of culture, globalization processes and consumer behavior.

\section{Broadening the Philosophical Modes of Inquiry}

Cultural studies have a pervasive impact within the academic fields of the humanities, the arts, and the social sciences (Sardar and Van Loon, 1999). Cultural studies have become influential not least because it has replaced "society" with "culture" as the central topic of study. The influence of cultural studies in marketing however has been minimized perhaps because of the additional political baggage associated with its origins. The ideological commitments of its founding fathers are in left-wing British politics (Hoggart, 2000). This criticism is unfortunate in that cultural studies has progressed beyond the now discredited line that industrial capitalist societies are uniquely responsible for the divisions along class, gender, and ethnic lines. Contemporary cultural studies contend that culture is the main arena where competing values are established and fought for, and where ascendant and marginalized groups resist the imposition of meanings imposed by others. Cultural studies elevate the role of culture in society and contend that culture shapes history as well as social structures. Hence history and culture are inseparable entities. Cultural studies has historically had a distinctly regional flavor. It has focused on the most pressing societal issues in each region's or country's social agendas. In the United States cultural studies have been less overtly political than in Europe and East Asia. North American cultural studies has focused on semiotics and literary theory. Consumer researchers have drawn extensively on semiotics and literary theory in their research and have examined a wide variety of media texts for their role in creating popular culture formations (Grayson \& Shulman 2000; McCracken 1989; Stern 1993). North American cultural studies has been criticized has been criticized by European researchers for being little more than a generalized form of textual analysis and free-floating theorization. North American researchers have countered that European cultural studies continues to be overpoliticized. Next, I will trace the scope of cultural studies, critique its intellectual foundations, and assess its utility as a guiding framework for cross-cultural consumer research.

Cultural studies is a disciplinary maverick; it lacks its own theories, principles, or methods. It straddles a broad intellectual landscape from old established disciplines such as sociology to new political movements such as postfeminism. Its modes of inquiry include Marxism, post-colonialism, text analysis, semiotics, feminism, structuralism and post-structuralism. Cultural studies is the quintessential "anti-discipline", moving from discipline 
to discipline according to its own agenda. The unifying philosophical framework of cultural studies is the investigation of the social and political context within which culture manifests itself and how power relationships in society shape cultural practices. Cultural studies may use semiotics or discourse analysis to examine the structures of power and locate discourse within wider historical, cultural and social relations (Goffman 1959; Kilbourne 2000; Williamson 1978). Contrary to popular notions of globalization as a deterministic, unidirectional force emanating from the United States, cultural studies do not assume that consumers accommodate passively to popular culture; consumers actively participate in the construction of meaning of cultural products they encounter in their daily life (Hoggart, 2000).

Cultural studies has seldom been value-free and its endeavors to address the process of globalization have frequently contained a distinctly anti-capitalist tone. Hoggart (1957/1998) suggests for example, that the study of British culture ought to focus on the ways and means by which mass media and imported American culture are "colonizing" the working classes. Concern for the working classes, caught between artistic and media elites is a central focus for British cultural studies. Indeed, the founding fathers of cultural studies at the Center for Contemporary Cultural Studies were all British and came from predominantly working class backgrounds. Focus on class politics however has not been popular in North America where people see themselves as coming from a more egalitarian, middleclass society. Williams (1958/1983) takes a more benevolent stance toward mass culture products. He notes that we can have good as well as bad mass culture, although the practice of assigning value what is inherently worthy or unworthy - is not an innocent enterprise. Values associated with mass culture products may be used to prop up existing ideological structures in ways that the creators of those products could never have envisioned. As Appadurai (1990) observes, the world economy can no longer be understood by assuming that the original producers of a product necessarily control its consumption. What does it mean for Beijing consumers that pizza is an Italian cuisine if the most prevalent franchise in the city is Pizza Hut?

Cultural studies have adopted various agendas of concern to researchers who focus on the process of globalization and cultural transformation. A central concern of Canadian cultural studies is the protection of Canadian experience in face of the blitz of movies, television programming, music, fashion and other cultural products coming from the United States. French cultural studies originally was concerned with the process of decolonization of the 1960's and its implications for French identity. More recently, French cultural studies have focused on the Americanization of France and signs of resistance. Technology is a driving force behind globalization and culture change (Cooper, 2002). The diffusion literature in marketing addresses the process of how new technologies are adopted by markets but does not focus on the social impacts of technology adoption on indigenous culture. Technoculture theory asserts that there is a linear, causal connection between advancements in technology and social progress. Cultural studies suggest that this perspective presents a passive relationship between culture and technology and therefore prevents us from asking critical questions. Cultural studies offer the perspective that technologies embody social and cultural forces that lie behind their development. These elements include lifestyles, ideas of nature, political philosophies, and systems of thought and are embedded in specific consumer products. Hence the personal computer comes with considerable cultural baggage; it represents an invitation to global connectivity and electronic democracy but also embodies the potential for Orwellian surveillance as transnational corporations monitor our purchases and surfing habits.

Cultural studies also address the diaspora of immigrant groups and the tensions created for individuals shedding old identities while groping for new ones. There is the ever-present desire for home while making the new home. Indeed the high suicide rates for second generation Latina teens in the United States is associated with the conflicting roles imposed upon them by their parents (the old) and the opportunity and expectations for individual choice presented via socialization with peers in school systems (the new). Cultural studies suggest that the diaspora space is inhabited not just by immigrants (e.g., post 1975 Orange County Vietnamese immigrants) but also by those who have stayed behind (e.g., present day South Vietnamese living in Vietnam) who are constructed and represented by diaspora intellectuals as "indigenous". Cultural studies also address the role of media as an emitter of globalization. From cultural studies we get the concept of media codes and how they can be internalized by target cultures as forms of mental representations. In the movie "Titanic", when the Rose character chooses Jack, she is not only opting for her true love, but also celebrating the triumph of individualism and the rejection of Victorian values associated with obedience to parental authority. 
Cultural studies argue the necessity of studying culture in the present, as a lived entity and not as some remote artifact of the past. The rhythms of everyday cultural change emerge in a more subtle form than the highly visible institutions and political upheavals that have made history of events. Alterations in mundane routines and rituals of everyday power are not usually found in official records (Farquhar, 2002). Yet it is precisely these routines and rituals that are of concern to marketers as they strive to position their products to fit the lived habitus of consumers. In historical ethnography social historians rely on an eclectic assortment of archeological artifacts such as legal cases, memoirs, business ledgers, birth and death records, letters and diaries to arrive at a master narrative of how people lived. This type of work however dates the arrival of cultural transformations long after they have already lost their immediacy for marketers (Corrigan and Sayer 1985).

In a country such as China which has experienced very rapid social change since the end of the Cultural Revolution, such historical approaches are likely to offer little utility for contemporary practicing marketers. Cultural studies however justify an expansion and a blurring of the boundaries between source materials that can serve as ethnographic text. National cultures resist globalization through a process of assimilating and appropriating meanings. Foreign cultures are quite capable of being imported into and being remade in a given national culture (Jameson, 1992). Hence, movies, novels, advertising, propaganda and critical journalism and other media products may take their place alongside fieldwork encounters as "reading matter" on culture. This approach has been described as a kind of itinerant ethnography that takes the role of transnational media more seriously in the production of cultural imaginations (Appadurai, 1996; Schein 1994). Itinerant ethnography is consistent with the earlier calls by Hogart (1957) for a critical reading of popular art to reveal the felt quality of life. Popular art can recreate life in its rich complexity and can allow us to move outside the time-dependent fabric of our daily experiences. Television commercials which often represent a hyper-ritualized version of cultural reality may serve as an excellent vehicle to observe cultural praxis (Tanaka, 1994). The use of television commercials as ethnographic artifacts permits us to achieve specificity and communality, while avoiding any claim of universality. Television advertising affords us an immediacy and access to a text rich in verbal and visual signs. The existence of the television commercial as cultural artifact avoids the limitations of phenomenology that claims that insights can only belong to particular unrecoverable events.

In sum, universalistic approaches to the study of culture cannot capture the dynamic processes of cultural change. The conversion of former communist countries to market oriented economies has brought about profound cultural change within those societies. Cultural studies offer a broad array of philosophical modes of inquiry and methodologies to assess the dynamic of cultural transformation. Cultural studies research have addressed a wide range of issues that are of concern to consumer researchers including; the effect of globalization on cultural transformation, nationalistic resistance to the perceived American domination of popular culture products, the cultural baggage associated with new consumer technologies, the diaspora of immigrant consumer sub-cultures, and the internalization of embedded meanings by target consumers of popular media products. Bourdieu (1966), one of the champions of French cultural studies, through his concepts of "habitus" and "hysteresis effect," provides a comprehensive framework for analyzing cultures in transition. I will describe this framework below and apply the concepts of habitus and hysteresis effect to an examination of consumer culture in post-Mao China. A frame analysis of a single mandarin language television commercial for McDonald's China will be used as an illustrative text.

\section{Habitus and the Hysteresis Effect}

Bourdieu (1984) maintains that social reality exists both inside and outside of individuals, both in our minds and in the products with which we surround ourselves. The concept of habitus emphasizes the mutually penetrating realities of individual subjectivity and societal objectivity. Bourdieu holds that objective structures in society have subjective consequences; that we are all individual actors in a socially constructed world. Habitus exits at many levels and cannot be reduced to either culture or psychological structure. It is more than role and less than national character. It may vary by class, region, community, or family, but it cannot be reduced to individual or collective behavior (Swartz, 1997). Bourdieu defines habitus as follows: "(it) is a system of lasting, transposable dispositions which, integrating past experience, functions at every moment as a matrix of perceptions, appreciations, and actions and makes possible the achievement of infinitely diversified tasks, thanks to analogical transfers of 
schemes permitting the solution of similarly shaped problems" (Bourdieu, 1971). Habitus is therefore a structure of dispositions, a tendency to act, and a limited set of potentials that might be realized in action. Since habitus is always generated in collective social practice, it cannot be reduced to the possession of an individual (Swartz, 1997).

The concept of habitus contains a number of features that make it a uniquely suitable philosophical framework for studying cultures negotiating their way with the forces of globalization. First, habitus abandons the classical individual/society dualism that has become institutionalized in contemporary Western academia, half appropriated by psychology which tends to monopolize the study of the individual, and half appropriated by sociology, which tends to monopolize the study of structures beyond individuals. Bourdieu sees the individual/society dualism as a carrier of political effects that contaminate the scientific enterprise; individual level explanations are associated with market oriented public policies, and society level explanations are associated with advocates of the welfare state. Indeed, this latter alignment goes some way to explaining why structuralist approaches in cultural studies have gained a wider academic audience in Europe than in the United States. That habitus can vary with levels of analysis makes the concept particularly appealing to marketers who are seldom interested in national culture characteristics in a strong sense. Market entry strategies typically focus on defined demographic and geographic market segments. Second, Bourdieu embraces the language of "strategy" to distance himself from strict structuralist forms of determination. Behavior is strategic rather than merely rule or norm conforming. He emphasizes the importance of agency within a structuralist framework. People in their everyday practice endeavor to move through a labyrinth of checks and opportunities they grasp imperfectly through past experience. In this view consumers are not merely rule followers, passively reacting to popular culture imports; they are active agents and practical strategists in the construction of their own consuming lives. The notion of people as practical strategists is then linked to social structures through the concept of habitus. This characteristic of habitus is consistent with marketing philosophy orientation of the sovereign consumer who actively constructs a psychosocial reality for himself or herself through consumption activities. Third, habitus tends to shape individual action so that existing opportunity structures are perpetuated. This concept explains why China's three generations, each of which occupy a different habitus, face a very different matrix of opportunity structures. Structural disadvantages - lack of access to educational capital associated with the generation aged 30 to 44 - tend to be internalized into relatively durable dispositions. Existing predispositions lead this generation to engage in maladapted behavior when faced with a newly structured environment - a socialist market economy. Fourth, the concept of habitus is conceptually appealing to both ethnographers and applied marketers since the notion transitions from micro- to macro- levels of analysis and permits us to generalize through quite different domains of human activity. Habitus can be linked to consumer schemas and scripts and suggest a common stamp across a broad sweep of different types of behavior, including motor, cognitive, emotional, or moral behaviors.

Under certain conditions there can occur a structural lag, or "hysteresis effect," between desires and changing opportunities. Habitus implies that people attend to the present and expect a future in terms of previous experience. When the environment is suddenly disrupted however, as occurred in China during the Cultural Revolution from 1966 to 1976, and again when Deng Xiaoping moved China towards a market socialist economy, previous experience may no longer be diagnostic for future behavior. The hysteresis effect shares some similarities to Ogburn's (1922) cultural lag hypothesis, where changes in the adaptive culture do not harmonize with change in the material culture. Habitus, as a relatively permanent set of dispositions enters into tension when it confronts objective conditions different from those in which it was generated. Adaptation and distinction are two types of agency juxtaposed in the concept of habitus. The hysteresis effect predicts that new practices emerge as a functional adaptation to the new necessities of life's chances. The desire to establish one's social status can now be satisfied through conspicuous consumption, or as simple an act as eating at a popular foreign fast food restaurant. Consumers who occupy the new habitus generate practices that differentiate themselves in terms of social status from their rivals. These practices, in turn, tend to reproduce new notions of social position since they establish a set of expectations for others occupying, or aspiring to occupy a similar habitus.

Next, I will apply the concepts of habitus and hysteresis effect in an analysis of food consumption practices in post-Mao China. In the investigation I adopt the approach of the itinerant ethnographer. For this study I have visited China three times. The focus of my ethnography is the cities of Hong Kong, Shenzhen, Guangzhou, and in particular, Beijing. In addition to the usual academic texts, other source texts for my study include a wide range of 
popular Chinese movies and documentaries, history books, memoirs, period and popular contemporary novels, propaganda and critical journalism, and television commercials. Specifically, I examine the role of the most visible of U.S. popular culture icons McDonald's. A single Mandarin language television commercial for McDonald's will serve as an illustrative text to describe the habitus of younger generation Beijingers. First, the cultural diffusion of Western fast food in China needs to be situated in the historical, political and social context of food during the Mao era.

\section{The Politics of Food Consumption in Post-Mao China}

In contemporary China, as in the Mao era, the consumption of food can be a highly visible act. During the difficult years of the Cultural Revolution, from 1966 to 1976, people in Maoist work units ate in canteens and seldom cooked at home. Theft of food could be seen as a revolutionary act since it represented theft from the state. The linking of food to politics is not new to China. The early nationalists agitated on a political platform based on hunger of the masses and gluttony of the powerful (Farquhar, 2002). Indeed, Mao's iron-fist hold on the Chinese Communist Party was severely tested after the disastrous Great Leap Forward (1958 to 1962) when an estimated 30 million Chinese died of starvation (Jasper Becker, 2000). From 1949 to the early 1980's communist revolutionary romanticism involved a deferral of appetites. Memoirs covering the period, such as Wild Swans (1992) describe much of the enjoyment of food as related to those rare occasions when there was an opportunity to indulge in forbidden gastronomy fare. Consumption of food luxuries was potentially a dangerous political act since the aroma of food could spread through courtyards and back lanes, identifying the home of the perpetrator. A strategy of distinction, in Bourdieu's terms, which attempts to create a novel habitus could bring about charges of "counterrevolutionary" from the watchful neighborhood committee. In a zero sum game, one always ate well at the expense of someone else who did without. Popular novels also address the politics of food. In A Small Town Called Hibiscus (1983/2001), food production and distribution needs to be rescued from the designs of local ideological zealots. The narrative implies that people need not only staples and simple foods but also the occasional delicacies necessary to affirm ritual life. The citizens of Hibiscus town can only return to bodily and spiritual fulfillment with the acceptance of free markets and the rejection of ideological extremism. At a deeper level, A Small Town Called Hibiscus argues that scarcity of food should not coexist with an overabundance of ideological language. Nonetheless, in present day China the moralistic rhetoric of the Communist Party, in official documents and propaganda, still urges collective sacrifice and the deferral of ostentatious consumption patterns. While many urban Chinese may have turned in their party card for a credit card, everyday life in China is still inhabited by the nation's Maoist past.

Chinese food is notably organized for groups and banqueting has become a powerful technique for building and maintaining social and business relationships (guanxi). Banqueting creates a ritual space in which the elements of guest lists, menus, seating hierarchies, and toasts all signify (Farquhar, 2002). Toasting provides an opportunity to demonstrate respect, while alcohol consumption deconstructs the boundaries that separate guests from hosts. Banqueting becomes a political act since it both dissolves and revises hierarchies of power and influence. In its discriminations and desires, the contemporary professional class Chinese rejects the politics of the egalitarian Maoist past. The Communist Party is sensitive to public resentment of ostentatious banqueting by public officials. People notice and resent what others are eating. While newspapers occasionally carry articles criticizing the opulence of local government official banquets, more central issues such as how those officials acquired the financial resources for such banquets, are quietly ignored (Becker 2000).

It is against this backdrop of the politics of food that we now turn to examine the role of that most visible of popular culture icons - McDonald's. The focus of my investigation is McDonald's Beijing and a single Chinese television commercial for McDonald's. The commercial, titled "Will You Marry Me" was produced by the advertising agency Leo Burnett, China. The narrative of the commercial would be utterly strange to Western consumers; that of a young man taking his girlfriend to McDonald's to make a proposal of marriage. The method I use is motivated by the same goals as Clifford Geertz's (1973) essay on cockfighting - to identify a cultural oddity that needs explaining and then placing it in a historical, ideological, and practical context until it no longer seems odd. The study of McDonald's represents an effort to situate the global in the local. The approach has the goal of making the McDonald's China television commercial not only understandable, but necessary. As we see below, 
globalization requires a series of compromises of both the transnational corporation and the local culture. Rather than a general diffusion of a standardized product, we have localization, compartmentalization, and hybridity.

\section{McDonald's in China}

\section{Will You Marry Me TV Commercial - The Narrative}

In the establishing shot we see a large yellow "M" on the window. We look through window to see a young couple, each drinking soda from a straw. There are other customers seated in the background, but none so intrusive as to threaten the romantic atmosphere (see appendix for commercial frames). The couple initially has both of their hands wrapped around the soda cup, perhaps intimating an initial shyness between our two protagonists. They both gaze downward toward the table and away from each other, avoiding eye contact. She wears a fashionable red sweater over a white tee-shirt and he sports a blue shirt, perhaps hinting at the colors of the American flag. Their clothing is conservative, smart and distinctively middleclass. The talent is good-looking and ethnically Chinese. As the camera zooms in on our couple, the giant yellow "M" disappears in a slow dissolve. He says hesitatingly, while gazing in her direction "...the coke...seems especially icy...today..." The reference to the icy coke is significant since it both nervously hints at the quality of their relationship and marks for the television audience that coke is meant to be served cold. In Chinese medicine cold drinks are not considered as healthy as hot beverages. His body language has now changed and become more open; he holds the cup of coke with one hand - his left - while leaving the hand closest to her free. She continues to play coy; gazing downward at the table, but then acknowledges him with a quick glance. The frame dissolves to indicate to the viewer that some time has past. He says "...the fries... also smell especially good..." Like the coke, the fries have been anthropomorphized; they smell good because she smells good. Now their body language has become more intimate; they are physically closer together and they arch their bodies in a cozier, more circular arrangement. Significantly, now that she has put down the coke, his left hand is close to her two hands. The television audience shares his sense of awkwardness as he briefly raises his eyes upward, perhaps a prayer for inspiration. There is another frame dissolve to indicate more time passing. Plot structure may be linear but the commercial is not depicted in real-time. Chinese marriage proposals, even in a postMao era, must take longer than thirty seconds. He says “...the chicken wings also...especially..." There is a pregnant pause; this time he leaves the sentence hanging without completion. With both hands, his grasps the precious red McDonald's box and carefully slides it over to her. She puts down her food. She grasps the container with both hands, as one would with any precious object. Cradling the box with one hand, she opens it with another. The close-up zoom reveals an engagement ring. Except for the McDonald's logo and the Chinese characters, the container resembles a jewel box. A spotlight on the ring saturates the frame in a radiant white glow. The music also hesitates, paralleling the action with the patented McDonald's piano note skip, echoing the rhythm of his beating heart. She pulls out the ring and smiles contently. The camera lens pulls back on his face; he looks relieved and clasps his hands together. She looks in his direction and responds in a pokerfaced fashion - "Where're the chicken wings?" There is little doubt however that the plot movement in this mini drama will end with the happy union of our two protagonists.

\section{McDonalds in China: A Locus of Contested Meanings}

The yellow arch symbol we see in the opening frame of the commercial is an icon of transnational business and popular culture. The symbol arouses strong passions worldwide; motivating a disgruntled French farmer, Jose Bovee to drive his truck though the doors of a McDonald's franchise as an expression of protest against this symbol cultural homogenization and Yankee imperialism. Those who write about cultural imperialism argue that it is domination of popular culture - rather than military or political hegemony - that matters most in a postmodern, postsocialist, post industrial world. McDonald's has become a saturated symbol, laden with contradictory associations and meanings - modernity and imperialism, homogenization and local responsiveness, local equity ownership and global corporation - so that the company is not fully in control of its image (Watson, 1997). Indeed, since the early 1970's an entire generation of Hong Kong children has been nurtured on Big Macs, fries and a coke so that McDonald's is now perceived as local fare. The concept of local ownership of a global brand may seem strange to North Americans, but the all-American hotdog was once considered uniquely German foodstuff. In the realm of popular culture it can be difficult to distinguish between what is local and what is foreign (Harvey, 1989). 
While McDonald's retains 50\% financial stake in most international franchises, the locals control the rest, thus blurring the distinction between global and local. Appadurai (1996) who writes of the deterritorialization of popular culture, argues that the world economy can no longer be understood by assuming that the original producers of a commodity necessarily control its consumption.

The success of McDonald's in China - there were 511 stores in 2002 - would not be possible without the type of hysteresis effect that occurred in China in the post-Mao era. The late 1980's saw a dramatic but contested movement towards individual control of wealth. In urban China the unisex trousers and jackets of the Maoist era were quickly replaced by miniskirts and motorcycle jackets, instantly marking gender. The generation gap in China is more marked than elsewhere. There is a very clear cohort effect. The "spoiled" children of the reform era neither understood nor internalized the asceticism and collective morality of their parents. An entire history of values and practices are entailed simply by chronological age (Farquhar, 2002). Bourdieu's hysteresis effect suggests that this is akin to a historical bodily stutter marking the impossibility of the pre-reform era generation feeling comfortable in the present. The habitus they embodied is ill-adapted to the changing conditions of a post communist era. Conflicts arise between different age cohorts because opposing habitus were produced by different modes of generation. Different habitus cause one group to experience as natural and reasonable practices or aspirations which another groups thinks unthinkable. These differences are inculcated by the conditions of everyday life in a postsocialist reform process that quietly evolved, beneath the din of much debated politics, over the course of a decade. In contemporary urban China decisions regarding consumption no longer require consultations with an extended network of parents, grandparents, adult siblings, and other kin. Women are working outside of the home in increasing numbers, which in turn is affecting gender relations, child rearing practices, and residence patterns (Becker, 2000). China's single child policy has helped produced a generation of "spoiled" Little Emperors. McDonald's has contributed in no small part to this new habitus. However, the process of localization for McDonald's has been a two-way street. It requires changes in local culture as well as modifications in the company's standard operating procedures (Yan, 1997).

Although McDonald's Hong Kong has made the transition from U.S. import to local institution, generational succession has not yet occurred in mainland China. Until mainland China's present generation of child consumers grow to have children of their own, McDonald's will continue to be perceived as something not entirely local. Nonetheless, Beijing customers have quietly but stubbornly transformed their neighborhood McDonald's into a concept very different from McDonald's in London, Paris or New York. Local management in McDonald's Beijing caters to three market segments: young couples, yuppies and children (who drag their parents along). Our protagonists in the television commercial clearly fall into the first market segment. The question I address here is why is the habitus of eating in McDonald's so different for these young Beijingers than for their counterparts elsewhere? There are a number of elements to McDonald's localization strategy that are critical to understanding these differences in meanings. McDonald's Beijing promotes the image of McDonald's as an exemplar of modernity, executed by local management. For young couples, McDonald's is an integral part of their lifestyle system, a way for them to participate in a transnational cultural system. The mutually penetrating realities of individual subjective consumption choices amid new available societal opportunities in a more permissive and expansive economy make this an ideal location to study habitus. Armed with imperfect knowledge of Western consumption scripts, Beijing consumers engage in strategy choices to distance and distinguish themselves from each other, and from the limited modes of consumption expression afforded to their parents.

The promise of McDonald's is not just fulfilling food, but fulfilling experience. It is not unusual to see young males arriving with their girlfriends and enjoying themselves in the restaurant for more than an hour. McDonald's U.S. may see itself as a quick service restaurant, but in Beijing the "quick" refers to food production, not consumption. McDonald's presents an arena of contested meanings; those offered for consumption by the transnational parent corporation, and those chosen by the locals from a broad menu of experiential possibilities. Eating foreign food has become an important way for young Beijingers to participate in a middleclass habitus. Over time experimental strategies become operating scripts which in turn become social expectations for newcomers, establishing and reinforcing the legitimacy if the new habitus. It is instructive to observe the behavioral responses of frequent McDonald's customers as they frown on new-comers from the countryside who violate queuing etiquette, thus ensuring the latter's speeded up socialization. Similarly, younger Chinese yuppies can be observed taking their 
trays to the garbage bins, having observed the behavior of Westerners; an entirely foreign custom to older Chinese who seem surprised at this example of Western egalitarianism.

The ambiance in McDonald's is carefully constructed to be comfortable and romantic. The restaurants are clean, feature popular light Western music, and friendly staff, and except during busy periods, they are relatively quiet. The menu offers foreign exotica of milk shakes, Big Macs and yogurt, all of which make McDonald's Beijing an inviting location for a romantic tryst. Bourdieu's notion of strategy relates to an idea of action that cannot be understood as merely compliance to norms or rules, whether those rules and norms be local or proffered by the transnational entity. Individuals engage in self-interested conduct which though bounded by normative expectations, offers choice within the constraints of the habitus. Choices do not derive directly from objective situations in which they occur; they stem from practical dispositions that incorporate ambiguities that emerge from acting through time and space. Consumers are not merely norm obeyers but strategic improvisers who respond to opportunities and constraints offered by various situations (Bourdieu, 1993). McDonald's may offer an alcohol-free environment to encourage an implied contract of quick food in return for quick consumption. Consumers are free to contest this meaning, as apparently many females do when they seek out McDonald's as a sanctuary from male-dominated inebriated environments. Traditional Chinese restaurants can become locations of competitive dining, where neighboring tables participate in a ritual of ostentatious display of ordering exotic and expensive foods. In such an environment, young male suitors on limited budgets risk losing face. Although McDonald's fare is not an inexpensive offering, potential costs of a date can be accurately predicted. This process proceeds in terms of circular relations that unite structures and practices. Objective structures - freedom from competitive dining and known calculus of costs - produces subjective dispositions to produce structured actions, which in turn, tend to reproduce objective structure, a consumer script for dining behavior.

In several McDonalds' franchises in Beijing remote service areas offer tables for two; often referred to by staff as "lovers corner". McDonald's also represents a safe environment for young couples since it offers a sanctuary from alcohol imbibing older males who might harass them. Hence the experience consumed in McDonalds by our young couple is not only a piece of Americana, but the possibility of participating in a thoroughly transnational culture system, with Chinese characteristics. Consumers who internalize similar consumption possibilities share the same habitus. Bourdieu (1984) argues that some kinds of class habitus tend to be more resistant to change than others. The French working class habitus is less adaptable to secondary socialization than middle class. The latter possess greater educational capital and hence adaptability. By a process of analogy, one might expect that younger generation Beijingers are more open to secondary socialization that those who spent their formative years in the Cultural Revolution. For marketers the implications seem to be that while it might be possible to manufacture new experiential possibilities for younger generation Chinese, the preferred strategy for older generation Chinese is accommodation to existing habitus.

McDonald's has acted as a cultural change agent in China. The Chinese, like most East Asians tend not to queue in line. Counter service situations can seem to Western eyes be to little more than unorganized free-for-alls. This lack of apparent civility often surprises Western travelers who have high expectations for Asian civility and politeness. Such civility and politeness however is reserved for in-groups who occupy a similar habitus. Younger Chinese customers seem to have adapted readily to other egalitarian practices of self-provisioning and self-seating. The process of internalization of objective structures is not only mental process but a corporeal one as well. Habitus is most powerful in explaining behavioral patterns in situations where normative rules are not explicit. Hence habitus and the hysteresis effect are most useful during times of significant cultural dislocation when ambiguities exist in behavioral scripts. At a more macro level, McDonald's Beijing has also been credited with raising the expectations of cleanliness in food service preparation at competing Chinese food outlets. A tour of the McDonald's kitchen is available on request, even to local competitors, of which there are now many. Other corporate culture expectations however have been adopted with more resistance. In Hong Kong, as in other parts of China, smiling customer service is not part of the menu. As a recent presentation by the Hong Kong Tourist Board, the speaker outlined the elements of an extensive marketing campaign to get Hong Kong service providers to offer more courteous service to tourists. Hong Kong customers, like their counterparts in other authority-ranking cultures, place heavy emphasis on public expressions of seriousness and look suspiciously on someone who smiles on the job. The implied social compact of quick food provisioning in return for quick consumption and exit, has not been adopted by 
Chinese customers. Customers seem intent on turning their neighborhood outlet into leisure centers. McDonald's also appears to have accommodated to the new habitus of the contemporary Chinese urban family, creating a uniquely Chinese style family atmosphere. Many parents no longer live with their married children in Beijing, and so McDonald's promotes itself as a family eating location, embodying the solidarity and harmony of the family extended family. This approach is reflected in its promotions slogan of "Get together at McDonald's; enjoy the happiness of family life".

\section{Conclusions}

Bourdieu's concepts of habitus and hysteresis effect offer consumer researchers an alternative to the false dilemma of the individual versus society dualism. Habitus fits well with marketing's orientation towards market segments, and the hysteresis effect is a useful conceptual tool to analyze cultures in transition from planned to market economies. Cultural studies offers a wide range of methodological tools and suggests a number of important agendas for cross-cultural consumer research. I have demonstrated in this article how the itinerant ethnography approach may be applied to the study globalization and popular culture. Itinerant ethnography provides an immediacy and thick description not found in universalistic studies of culture. Itinerant ethnography also suggests a wide range of source texts that may be used in the study of culture. The analysis of McDonald's Beijing demonstrates the necessity of situating the study of consumer popular culture in a historical context. The study of McDonald's also reveals that the fast food franchise is a site of contested meanings between producers and consumers of the product.

\section{References}

1. Appadurai, Arun (1996) Modernity at Large: Cultural Dimensions of Globalization. Minneapolis: University of Minnesota Press.

2. $\quad$ Becker, Jasper (1998) Hungry Ghosts: Mao's Secret Famine. Henry Holt.

3. $\quad$ Becker, Jasper (2000) The Chinese The Free Press, New York, NY.

4. Berger, Peter, L. and Samuel P. Huntington. Many Globalizations: Cultural Diversity in the Contemporary World. Oxford University Press.

5. $\quad$ Bhabha, Homi K. (1994) The Location of Culture. Routledge.

6. Bourdieu, Pierre (1971) "Intellectual Field and Creative Project," in Knowledge and Control: New Directions for the Sociology of Education, ed. M. Young, p. 161-188. London: Collier- Macmillian.

7. Bourdieu, Pierre (1979/1984) A Social Critique of the Judgement of Taste. Routledge \& Kegan Paul Ltd.

8. Bourdieu, Pierre (1993) The Field of Cultural Production: Essays on Art and Literature. New York. Columbia University Press.

9. $\quad$ Chang, Jung (1992) Wild Swans: Three Daughters of China. Anchor World Views.

10. Cooper, Simon (2002) Technoculture and Critical Theory: In the Service of the Machine? Routledge Studies in Science Technology and Society.

11. Corrigan, Philip, and Derek Sayer (1985). The Great Arch: English State Formation as Cultural Revolution. London. Blackwell.

12. De Mooij, Marieke (1994) Advertising Worldwide. New York, Prentice Hall.

13. Farquhar, Judith (2002). Appetites: Food and Sex in Post-Socialist China. Duke University Press.

14. Geertz, Clifford (1973). The Interpretation of Cultures. New York. Basic Books.

15. Goffman, Ervin (1959). The Presentation of Self in Everyday Life. Anchor Press.

16. Grayson, Kent, and David Shulman (2000). "Indexicality and the Verification Function of Irreplaceable

17. Possesions: A Semiotic Analysis," in Journal of Consumer Research. 27, (June), p17-30.

18. Gu, Hua (1983/2001) A Small Town Called Hibiscus. Translation Gladys Yang. China Books and Periodicals, Inc. San Francisco.

19. Hampden-Turner, Charles, and Fons Trompenaars (2000) Building Cross-Cultural Competence: How to Create Wealth from Conflicting Values. Yale University Press.

20. Harvey, David (1990) The Condition of Postmodernity: An Enquiry into the Origins of Cultural Change. Blackwell Publishers.

21. Hofstede, Geert (1991) Cultures and Organizations: Software of the Mind. London. McGraw-Hill 
22. Hofstede, Geert (1994) "Management Scientists are Human.” In Management Science, 40 (1), p. 4-13.

23. Hoggart, Richard (1998) The Uses of Literacy. Transaction Publishers: Classics in Communications and Mass Culture Series.

24. Hoggart, Richard (2000) First and Last Things. London Bridge Trade.

25. Jameson, Frederic (1992) Postmodernism or the Cultural Logic of Late Capitalism. Duke University Press.

26. Kilbourne, Jean (2000) Can't Buy My Love: How Advertising Changes the Way We Think and Feel. Touchstone Books.

27. Kovacs, Janos Matyas (2002) "Rival Temptations and Passive Behavior: Cultural Globalization," in Many

28. Globalizations: Cultural Diversity in the Contemporary World. Eds. Peter L. Berger and Samuel P. Huntington. p. 146-182. Oxford University Press.

29. McCracken, Grant (1989). "Who is the Celebrity Endorser? Cultural Foundations of the Endorsement Process," in Journal of Consumer Research, 16, (December), p.310-321.

30. Ogburn, William (1922) Social Change. New York. Viking Press.

31. Sardar, Ziauddin, and Borin Van Loon, (1999). Introducing Cultural Studies. Icon Books. Cambridge.

32. Schein, Louisa (1994) "The Consumption of Color and the Politics of White Skin in Post-Mao China," in SocialText. 41, (winter), p. 141-164.

33. Srinivas, Tulasi (2002) "A Tryst with Destiny: The Indian Case of Cultural Globalization.” In Many

34. Globalizations: Cultural Diversity in the Contemporary World. Eds. Peter L. Berger and Samuel P. Huntington. p. 89-116. Oxford University Press.

35. Stern, Barbara, B. (1993). "Feminist Literary Criticism and the Deconstruction of Ads: A Postmodern View

36. of Advertising and Consumer Responses," in Journal of Consumer Research, 19, (March) p556- 566.

37. Swartz, David (1997). Culture and Power: The Sociology of Pierre Bourdieu. The University of Chicago Press, Chicago.

38. Terpstra, Vern, and Kenneth David. The Cultural Environment of International Business. Cincinnati, OH: Southwestern Publishing Co.

39. Watson, James (1997) Golden Arches East: McDonald's in East Asia. Stanford University Press.

40. Williams, Raymond (1983) Culture and Society: 1780-1950. $2^{\text {nd }}$ Edition. Columbia University Press.

41. Williamson, Judith (1978). Decoding Advertisements: Ideology and Meaning in Advertisements. Marion Boyars.

42. Yan, Yunxiang (1997). "McDonald's in Beijing: The Localization of Americana," in Golden Arches East: McDonald's in East Asia. Ed. James Watson. Stanford University Press, p. 39-76.

\section{Appendix}

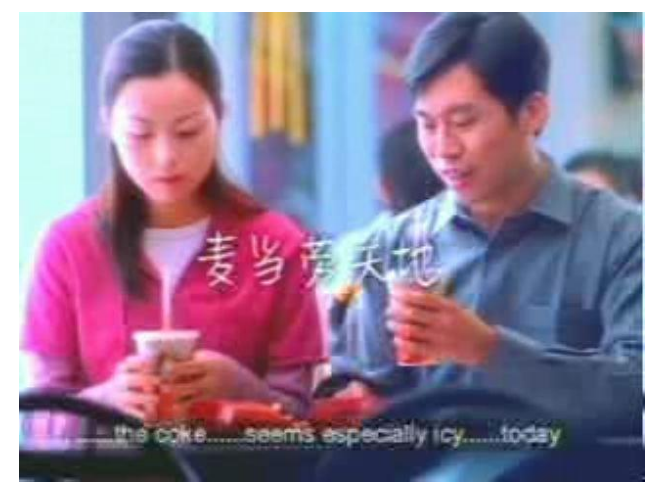

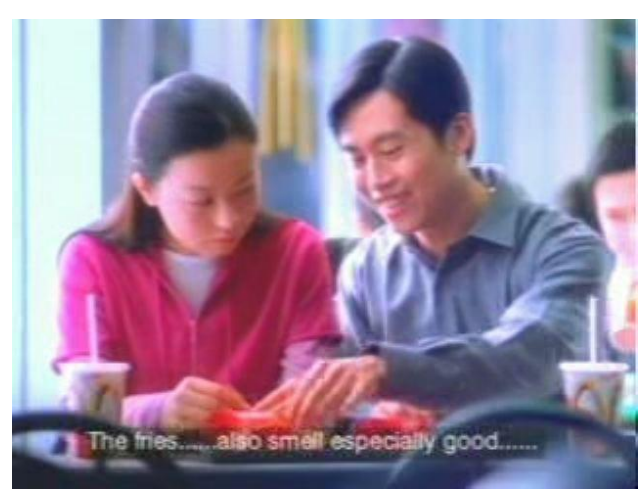



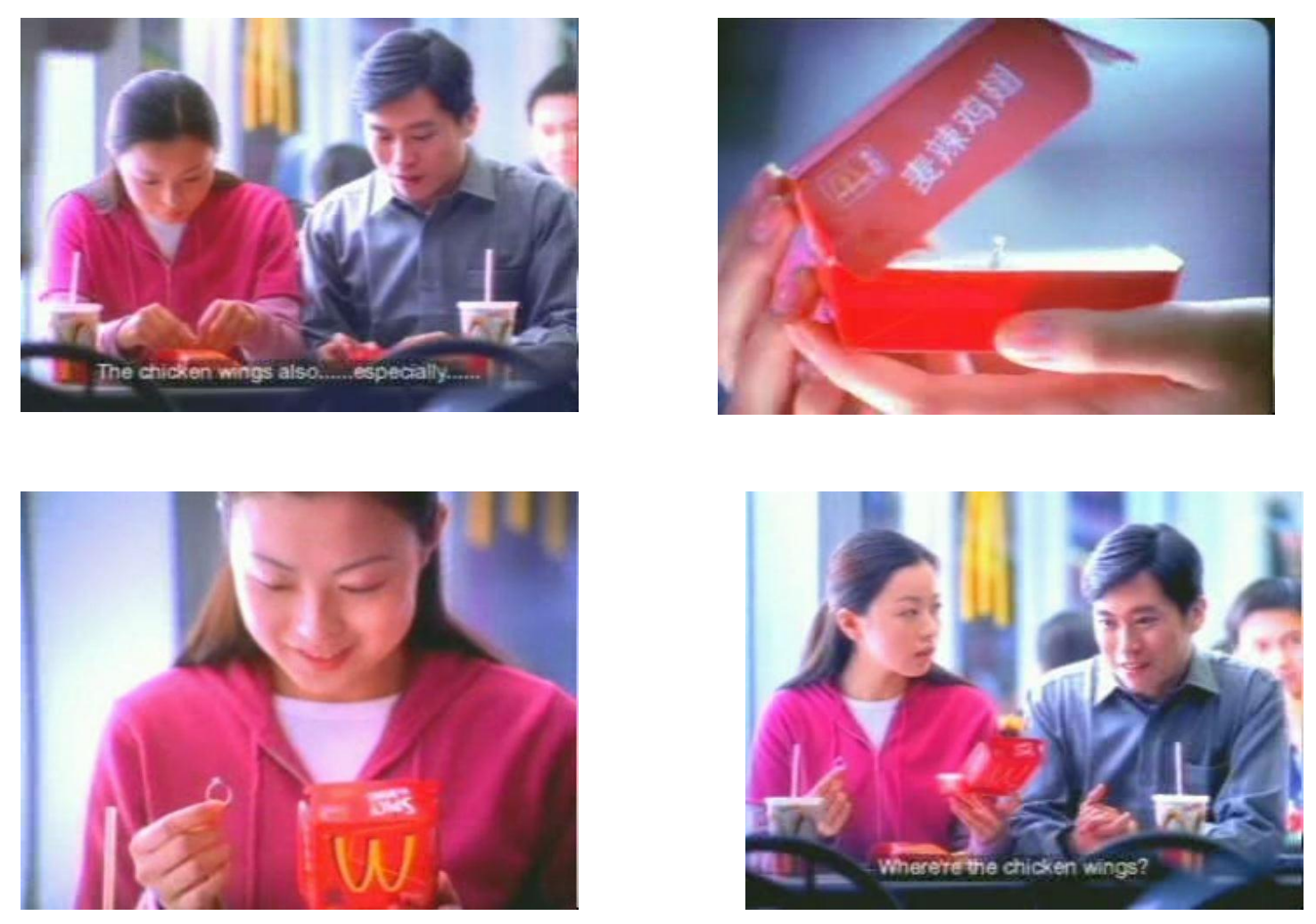